\title{
An assessment of the relationship between shared solid waste management services and effectiveness in service delivery in Kampala Capital City Authority, Uganda.
}

\author{
${ }^{1}$ Nabukeera Madinah, ${ }^{2}$ Ali Boerhannoeddin, ${ }^{3}$ Raja Noriza Binti Raja Ariffin \\ ${ }^{I}$ Department of History and political science, P.O.Box 1 Kampala Uganda, Kyambogo University \\ ${ }^{2}$ Department of Administrative studies and Politics Faculty of Economics and Administration Kuala Lumpur \\ P.O. box 50603 Malaysia \\ ${ }^{3}$ Department of Administrative studies and Politics Faculty of Economics and Administration Kuala Lumpur \\ P.O. box 50603 Malaysia
}

\begin{abstract}
This manuscript assesses the effectiveness of KCCA in management of solid waste in Uganda through a theoretical framework of 'social welfare', 'standardization', 'effectiveness', 'efficiency', 'equity', 'economies of scale and scope', 'cost', 'quality' and 'quantity' (SSEEEECQQ). This study attempted to assess the relationship between sharing and the effectiveness of solid waste management services without considering other variables listed in the framework domain. The main instrument used to collect data was a questionnaire though informal discussions were included to supplement quantified results. Two categories were investigated i.e., (a) staff of KCCA at operational and senior level, and (b) town dwellers. The overall results indicate that sharing solid waste services significantly affects the implementation process, the supervision, trust between the community members and partnerships since the $p$-values are all less than 0.05. Moreover, the approach of sharing waste management resources among divisions i.e., (a) refuse trucks, (b) casual workers, and (c) heavy equipments has helped to improve service delivery in waste management.

Hopefully the findings will help dwellers appreciate a shared responsibility of maintaining a clean city and policy makers will appreciate the need to draft a policy that will guide shared service operations which model can be replicated in many municipalities in Uganda to nurse the desire of achieving a competent and enterprising public service at the same time maintaining a clean city.
\end{abstract}

\section{Introduction}

Societal and financial deviations have affected the state of solid waste management in poor developing countries. This coupled with increased requests by the voters for greater standards in solid waste management and a fiscal depression at the start of the 1990s have continuously controlled the state in which, uniquely, the responsibilities of the public authorities have turned out to be more difficult and changed while, on the other side, monetary capital is deteriorating at an equal level (Steiner, 2003). (Belloc \& Pagano, 2005; C. Wood, 2006; C. H. Wood, 2004) argued that, public-public partnerships have developed as a system of choice for numerous authorities in the provision of urban services. Confronted with merged trials and partial resources, inter-organizational partnerships are gradually recommended as the tool to advance the effectiveness and efficiency of public services.

(Stephen P Osborne, 2010; S.P. Osborne, 2010) terms it as, an era of complex and 'fragmented service delivery system' for public services. Different countries use various terminologies to describe collaborative inter council undertakings i.e., 'inter-jurisdictional agreements (IJAs), (Andrew, 2009), inter local agreements (Carr, LeRoux, \& Shrestha, 2009), networks, mergers or alliances, partnerships, collaborations'(Andrews \& Entwistle, 2010) and shared services in Australia (Dollery \& Akimov, 2008) and the United Kingdom (Tomkinson, 2007), they commonly signify established methods for dealing with common social challenges in fragmented local government structures and systems. (Oakerson, 1999), defined "shared services as an agreement involving two or more public organizations cooperating to render services for the common good of the people".

Waste management is the creation, reducing, categorizing, supervising, handling, treatment, reprocessing and enduring collection of solid waste on a daily basis.

\section{Background}

The decentralization of solid waste management intensified in 1997 when the Local government Act (GoU, 1997) was enacted and divisions became more powerful politically to manage their affairs in terms of service delivery. The objective was to reduce the workload from the central to the local level to enable the delivery of the much needed services to the people. Unfortunately this was not the case, the practice conflicted with the theory and solid waste management worsened including the landfill management in Kitezi. There was a 
lot of indiscriminate waste disposal habits among the residents, lack of trade order that left city roads dirty, unregulated life style in waste generation, unwillingness to pay for waste collection services, inability to afford levied charges, lack of possession of homes that significantly contributed to man-made floods in the city (G. o. U. KCCA, 2011). Such a state of affairs needed a novel method to improve solid waste management in Uganda.

Shared services stem from the private sector, and is seen as an adapted model in public sector that is primarily in its phases of growth. By taking into account the private sector contribution on the literature, it is possible to identify the inter- relationship between performance and operation of shared services within the public sector. The main reasons meant for initiation of shared services is attaining additional cost-effective service delivery that include returned competitive edge and greater quality (Triplett \& Scheumann, 2000).

According to theorists, shared services can improve bottom line performance, increase firm competitiveness, enhance firm's architectural liveliness by easing change towards new structural business reforms like 'Shared service organizations' and 'service oriented enterprises' (Bergeron, 2003a, 2003b; Janssen \& Joha, 2008), shared service in private sector may advance structural knowledge and revolution by centralizing technical and managerial expertise and enabling information sharing (Cooke, 2006). It is on the basis of this back ground that public sector embraced the shared service model in waste management to improve service delivery under the new City management of KCCA. This study therefore investigates the relationship between sharing waste management services and effective performance among the five divisions of KCCA i.e., Kampala central, Lubaga, Nakawa, Makindye and Kawempe.

Largely, the review of shared services engagements through both private and public sector discloses that there is inadequate published works on the effectiveness of a diversity of shared service models and engagements. According to the literature, some single cases have been a success factor in highlighting the features in the operation and performance of shared service preparations a case in point like; (Dollery \& Crase, 2004; Dollery, Grant, \& Akimov, 2010; Madinah, 2015; Murray, Rentell, \& Geere, 2008; Pike, 2012; Redman, Snape, Wass, \& Hamilton, 2007a, 2007b). It should be observed that evidence is not clear since services investigated were back office services like procurement, account payables, human resource management and information technology. What is not clear is whether 'shared service may result into reduced costs for services like waste management that a consumer is able to evaluate'; this is as a result of the limited scope given to shared services hence a clear gap to be investigated. This study can therefore claim the novelty of assessing the relationship between sharing and effective waste management using the (SSEEEECQQ) frame work.

\section{Measuring shared service performance in waste management}

(Oates, 1998; Quinn, Cooke, \& Kris, 2000) reflected on shared services as an action of sharing services outside the borders of a solitary structural entity to improve service delivery.

Based on the literature review, it is evident that there are at least 9 components hidden within the models; such as social welfare, standardization, effectiveness, efficiency, equity, economies of scale and scope, quality, quantity and customer focus in the construct of shared services, (SSEEEECQQ) i.e., standardization (Ruggini, 2006), social welfare, (Buchanan, 1965), effectiveness, (Buchanan, 1965), efficiency, (Tomkinson, 2007), equality, (Buchanan, 1965); economies of scale, (Tomkinson, 2007); quality and quantity (Oakerson, 1999), and cost (Buchanan, 1965; Dollery et al., 2010; Oakerson, 1999; Tomkinson, 2007). However this paper is only looking at effectiveness and the rest of the eight variables are outside the scope of this research.

(Wiener, 1988) defines effectiveness in terms of both the competence (efficiency) of the changed practices and how well the service or product is transferred into the surroundings and recycled back into usable inputs for the organization. i.e., effectiveness is simply doing things in the right way to achieve a set objectives (Drucker, 2006). Effectiveness is ability to perform as expected or being result oriented. At the end of the day, there must be results handy to account for what has been done. (Drucker, 2011). Also recognizing reasons that underly the accomplishment of the business objectives is termed as effectiveness, (Fotiadis, Vassiliadis, \& Piper, 2014) and according to (Boyne, 2002) effectiveness is the 'attainment of the official goals of the services'

The effectiveness of the shared services arrangement is also believed to be dependent on the effectiveness of the implementation process (Borins, 2001; Dollery, Akimov, \& Byrnes, 2009; Piening \& Warsh, 2002) and the trust among partners is equally a key success factor of shared services public- public service delivery.

\section{Quantifying effectiveness in solid waste management} Table 3.3 Indicators of Effectiveness for KCCA in SWM services

\begin{tabular}{|c|c|c|}
\hline Criteria & Performance indicators & Target \\
\hline Effectiveness & $\begin{array}{ll}\text { (i) } & \text { Shared services health/solid waste management } \\
\text { - } & \text { Effectiveness of the implementation process } \\
\text { - } & \text { Levels of supervision } \\
& \text { Levels of trust of the partners in the partnership }\end{array}$ & $\begin{array}{l}\text { Directors KCCA \& } \\
\text { senior officials } \\
\text { Employees of KCCA in } \\
\text { public health } \\
\text { department } \\
\text { Mayors, Deputy Mayor, }\end{array}$ \\
\hline
\end{tabular}


An assessment of the relationship between shared solid waste management services and ......

\begin{tabular}{lll}
\hline & & \\
& & Partnership dissolve due to selfish interests \\
& Partnerships control and supervision & \\
\hline
\end{tabular}

Source: Researcher

\section{Methodology}

The use of a dominant principle of quantitative and qualitative approaches in a mixture to provide a better understanding of shared services in operational services like waste management and to a appreciate the difficulties involved in using either approaches single handedily,(Creswell \& Clark, 2007). A quantitative questionnaire was distributed to two categories i.e., the workers in KCCA in waste management section and Kampala dwellers . Futhermore,informal discussions where conducted among dwellers, private waste collectors and contract and causal employees in KCCA to determine whether the shared solid waste management model has improved service delivery in the City.

\section{Size Calculation for Proportionate to Population Size (PPS) Sampling}

The total sample size was calculated using chris and morgan table. From the estimated population of 2.5million, the sample was 723. Using cluster sampling, the process ended at two stages: the sampling interval was calculated to get 30 clusters consisting of heads of the household in terms of paying waste management bills. Next step was to determine the number of individuals to be sampled in each cluster using a formula:

$$
\text { Number to sample cluster }=\frac{\boldsymbol{n}_{p p s}}{m}
$$

Where ${ }^{n}$ pps $=$ sample size proportionate to population size

$\mathbf{m}=$ the number of clusters

Therefore, Sample Size Calculation for Proportionate to Population Size (PPS) sampling of the study runs as:

$$
\frac{723}{30}=24.1
$$

Sample units are always rounded up on the number of individuals to survey per cluster, which made it 24 per cluster.

Table 3.11. List of 30 parishes from all divisions were questionnaires were distributed.

\begin{tabular}{lll}
\hline Division & Number of parish & Names of parishes were questionnaires were distributed \\
\hline 1. Central & 3 & Industrial area, Kisenyi and Nakasero \\
2. Kawempe & 6 & $\begin{array}{l}\text { MakerereII, BwaiseI, Mulago, Wandegeya, KawempeII and Kazo - Angola } \\
\text { Kibuye, Kibuli, Kisugu, Kansanga, Bunga, Katwe, Monitor publication and } \\
\text { Namuwongo. }\end{array}$ \\
& 8 & \\
& 6 & Bukoto I, Luzira, Mbuya, Banda, Nakawa, and Naguru \\
4. Nakawa & 7 & \\
5. Rubaga & 30 & \\
\hline Total & & \\
\hline
\end{tabular}

To determine this improvement, a chi-square was performed, correlation and regression analysis to test whether the sharing model has an impact on waste management improvement in terms of effectiveness.

\section{Results and discussion}

The chi-square test was used to test whether sharing services has significant relationship with effectiveness in solid waste management services. The effectiveness in the services was measured in terms of the implementation process of sharing, supervision of activities, trust of partners, selfishness among partners in the partnership, control and distrust among partners.

The study further revealed that sharing solid waste services also has a significant effect on the degree of effectiveness of service delivery. Sharing solid waste services significantly affects the implementation process, the supervision, trust between the community members and partnerships as seen in table: 1 where the $p$ -values are all less than 0.05 . This enhances effectiveness in service delivery.

Table: 1 chi-square results for the association between shared solid waste and effectiveness in service

$\begin{array}{lcc}\begin{array}{l}\text { Variable } \\ \text { Costs }\end{array} & \begin{array}{c}\text { delivery } \\ \text { Chi-square Value }\end{array} & \text { P-value } \\ \begin{array}{l}\text { Effectiveness } \\ \text { 1.Implementation process }\end{array} & 38.927 & \\ \text { 2.Supervision } & 48.556 & 0.000 \\ \end{array}$


An assessment of the relationship between shared solid waste management services and ......

$\begin{array}{lll}\text { 3.Trust of partners } & 126 & 0.000 \\ \text { 4.Selfishness } & 85.127 & 0.000 \\ \text { 5.Control } & 62.246 & 0.000 \\ \text { 6.Distrust } & 43.378 & 0.000\end{array}$

The correlation test in table: 2 between sharing solid waste services and effectiveness showed that there is a positive relationship between sharing solid waste services and the level of effectiveness. In terms of implementation process it gets better as sharing increases $\left(\rho=-0.00^{* *}, \square=0.062^{*}\right)$

The more the sharing the less the supervision $\left(\rho=-0.00^{* *}, \square=-0.033^{*}\right)$ implying that the more partners build some level of trust through sharing, the more the partners trust each other $\left(\rho=-0.00^{* *}, \square=0.017^{*}\right)$, increased level of sharing leads to less selfishness $\left(\rho=-0.00^{* *}, \square=-0.093^{*}\right)$ since all the government departments are working to achieve the same goals and the as sharing improves there is less distrust among partners $\left(\rho=-0.00^{* *}\right.$, $\left.\square=-0.012^{*}\right)$.

Table 2: Relationship between shared shared sold waste services and effectiveness in service delivery

\begin{tabular}{|c|c|c|c|c|c|c|c|}
\hline & $\begin{array}{l}\text { Shared } \\
\text { solid waste } \\
\text { services }\end{array}$ & $\begin{array}{l}\text { implementation } \\
\text { process }\end{array}$ & supervision & $\begin{array}{l}\text { trust } \\
\text { of } \\
\text { partners }\end{array}$ & selfishness & control & Distrust \\
\hline $\begin{array}{l}\text { implementation } \\
\text { process }\end{array}$ & $0.062 *$ & 1.000 & & & & & \\
\hline supervision & $-0.033 *$ & 0.010 & 1.000 & & & & \\
\hline trust of partners & $0.017 *$ & $.774(* *)$ & 0.111 & 1.000 & & & \\
\hline Selfishness & $-0.093 *$ & $.464(* *)$ & $.550(* *)$ & $.732(* *)$ & 1.000 & & \\
\hline Control & 0.075 & 0.005 & $.730(* *)$ & 0.158 & $.605(* *)$ & 1.000 & \\
\hline Distrust & $-0.012 *$ & $.537(* *)$ & $.360(* *)$ & $.687(* *)$ & $.774(* *)$ & $.546(* *)$ & 1.000 \\
\hline
\end{tabular}

**.Correlation is significant at the 0.01 level (2-tailed) *Correlation is significant at 0.05 level (2-tailed)

\section{Conclusion}

The sharing model has been operationalized through assessing the relationship of sharing and the effective dimension and there is proof from the respondents that indeed the sharing model exists and has contributed to improvements of waste management services in Kampala. Though correlations are low, they have a significant impact on determining the effective performance in service delivery.

Generally KCCA is effective in waste management though its performance has not reached the desired level, this could be attributed to; (i) total government support, (ii) motivated employees and, (iii) a reasonable level of autonomy that was awarded to KCCA thorough alegal instrument (KCCA, 2010; Madinah, 2014) with specific objectives to achieve i.e., increase waste collection efficiency and improve the sanitation of the city.

Although KCCA is still new in the administration of the city, it has demonstrated modest changes in sanitation and beautification of Kampala City simply because it embraced new work methods through sharing refuse trucks, casual workers and heavy equipment to reduce on the accumulated garbage backlogs that were inherited from KCC. Since theory argues that effectiveness of sharing highly depends on how it is implemented, results are in line with theorists since the implementation process becomes better as sharing develops. It should be observed that shared services have their flaws since their success highly depends on how well they are implemented (Dollery, et, al. (2010).

Data from informal discussions and reports indicated that efficiency in solid waste has improved from 45- 55\% of the generated waste in the city, an implication that KCCA has performed better than KCC. Town dwellers are impressed with the improvement in sanitation though a lot needs to be done especially in slums and drainage channels. They are also worried of displacement since the KCCA is passionate about trade order. The sharing model could be an answer to the pending problems of an inefficient public service in Uganda.

Hence if carefully managed and implemented, it might solve all societal challenges that individual divisions and districts cannot solve independently and the novel arrangement should be encouraged since it is likely to reduce costs by reducing on supervision.Enteprises governments aim at generating resources before expenditure,through shared services, government can generate a lot of income while implementing the amended solid waste management ordinance since the existing one does not much the current vision of KCCA. In order to create sanity in the city, shared service policy should be drafted to support in guiding its operations.

\section{References}

[1]. Andrew, S. A. (2009). Regional Integration Through Contracting Networks An Empirical Analysis of Institutional Collection Action Framework. Urban Affairs Review, 44(3), 378-402.

[2]. Andrews, R., \& Entwistle, T. (2010). Does Cross-Sectoral Partnership Deliver? An Empirical Exploration of Public Service Effectiveness, Efficiency, and Equity. Journal of Public Administration Research \& Theory, 20(3), 679-701. doi: 10.1093/jopart/mup045

[3]. Belloc, M., \& Pagano, U. (2005). Co-evolution paths of politics, technology and corporate governance: ECGI Working Paper Series in Law. 
[4]. Bergeron, B. (2003a). Essentials of Shared Services, John Wiley\&Sons. Inc., New Jersey, 93-95.

[5]. Bergeron, B. (2003b). Essentials of Shared Services. 2003: John Wiley \& Sons.

[6]. Borins, S. (2001). Encouraging innovation in the public sector. Journal of intellectual capital, 2(3), 310-319.

[7]. Boyne, G. A. (2002). Public and private management: what's the difference? Journal of management studies, 39(1), 97-122.

[8]. Buchanan, J. M. (1965). An economic theory of clubs. Economica, 1-14.

[9]. Carr, J. B., LeRoux, K., \& Shrestha, M. (2009). Institutional Ties, Transaction Costs, and External Service Production. Urban Affairs Review, 44(3), 403-427. doi: 10.1177/1078087408323939

[10]. Cooke, F. L. (2006). Modeling an HR shared services center: Experience of an MNC in the United Kingdom. Human Resource Management, 45(2), 211-227.

[11]. Creswell, J. W., \& Clark, V. L. P. (2007). Designing and conducting mixed methods research.

[12]. Dollery, B., \& Akimov, A. (2008). A Critical Comment on the Analysis of Shared Services in the Queensland Local Government Association's Size, Shape and Sustainability Program. Accounting, Accountability \& Performance, 14(2), 29.

[13]. Dollery, B., Akimov, A., \& Byrnes, J. (2009). Shared Services in Australian Local Government: Rationale, Alternative Models and Empirical Evidence. Australian Journal of Public Administration, 68(2), 208-219. doi: 10.1111/j.1467-8500.2009.00635.x

[14]. Dollery, B., \& Crase, L. (2004). Is bigger local government better? An evaluation of the case for Australian municipal amalgamation programs. Urban Policy and Research, 22(3), 265-275.

[15]. Dollery, B., Grant, B., \& Akimov, A. (2010). A typology of shared service provision in Australian local government. Australian Geographer, 41(2), 217-231.

[16]. Drucker, P. F. (2006). The Effective Executive: The Definitive Guide to Getting the Right Things Done (Harperbusiness Essentials). New York: Collins.

[17]. Drucker, P. F. (2011). The five most important questions you will ever ask about your organization (Vol. 90): John Wiley \& Sons.

[18]. Fotiadis, A. K., Vassiliadis, C. A., \& Piper, L. A. (2014). Measuring Dimensions of Business Effectiveness in Greek Rural Tou rism Areas. Journal of Hospitality Marketing \& Management, 23(1), 21-48.

[19]. GoU, G. o. U. (1997). Local Government Act. Uganda.

[20]. Janssen, M., \& Joha, A. (2008). Emerging shared service organizations and the service-oriented enterprise: Critical management issues. Strategic Outsourcing: An International Journal, 1(1), 35-49.

[21]. KCCA. (2010). Kampala Capital City Authority Act Uganda.

[22]. KCCA, G. o. U. (2011). Ministrial statement on affairs in KCCA Uganda.

[23]. Madinah, N., Boerhannoeddin, A., \& Ariffin, R. N. B. R. (2014). Performance Assessment of Public Service Organisations in Shared Solid Waste Services: A case for Kampala Capital City Authority in Uganda. . World Journal of Social Science, 1(2), 86.

[24]. Madinah, N., Boerhannoeddin, A., \& Ariffin, R. N. B. R. (2015). Performance Evaluation of Public Service Institutions (CQS) Framework. . World Journal of Social Science, 2(1), 1-12.

[25]. Murray, J. G., Rentell, P. G., \& Geere, D. (2008). Procurement as a shared service in English local government. International Journal of Public Sector Management, 21(5), 540-555.

[26]. Oakerson, R. J. (1999). Governing local public economies: Creating the civic metropolis: ICS Press Oakland, CA.

[27]. Oates, W. E. (1998). On the welfare gains from fiscal decentralization: University of Maryland, Department of Economics.

[28]. Osborne, S. P. (2010). Delivering public services: time for a new theory?

[29]. Osborne, S. P. (2010). The new public governance?: emerging perspectives on the theory and practice of public governance: Taylor \& Francis.

[30]. Piening, S., \& Warsh, R. (2002). Collaboration between evaluators and agency staff in outcome-based evaluation. Evaluation in Child and Family Services: Comparative Client and Programme Perspectives, 161-171.

[31]. Pike, T. (2012). An exploration of how shared corporate service operate and perform in English local government. Cardiff University.

[32]. Quinn, B., Cooke, R. S., \& Kris, A. (2000). Shared services: mining for corporate gold: Financial Times Prentice Hall.

[33]. Redman, T., Snape, E., Wass, J., \& Hamilton, P. (2007a). Evaluating the human resource shared services model: evidence from the NHS. The International Journal of Human Resource Management, 18(8), 1486-1506.

[34]. Redman, T., Snape, E., Wass, J., \& Hamilton, P. (2007b). Evaluating the human resource shared services model: evidence from the NHS. International Journal of Human Resource Management, 18(8), 1486-1506. doi: 10.1080/09585190701502612

[35]. Ruggini, J. (2006). Making local government more workable through shared services. Government Finance Review, $22(1), 30$.

[36]. Steiner, R. (2003). The causes, spread and effects of intermunicipal cooperation and municipal mergers in Switzerland. Public Management Review, 5(4), 551-571.

[37]. Tomkinson, R. (2007). Shared services in local government: improving service delivery: Gower Publishing Company.

[38]. Triplett, A., \& Scheumann, J. (2000). Managing shared services with ABM. STRATEGIC FINANCE-MONTVALE-, 40-45.

[39]. Wiener, Y. (1988). Forms of value systems: Focus on organizational effectiveness and cultural change and maintenance. Academy of management Review, 13(4), 534-545.

[40]. Wood, C. (2006). Scope and Patterns of Metropolitan Governance in Urban America Probing the Complexities in the Kansas City Region. The American Review of Public Administration, 36(3), 337-353.

[41]. Wood, C. H. (2004). Metropolitan Governance in Urban America: A Study of the

[42]. Kansas City Region. Unpublished Dissertation, University of Kansas. 